\title{
THE ARNOLD ARBORETUM DURING THE FISCAL YEAR ENDED JUNE 30, 1939
}

Fortunately for the best interests of the Arboretum it has been possible to accomplish much extra work in the grounds, in the field, in the laboratories, in the herbarium, and in the library through generous unrestricted and restricted gifts from numerous friends and supporters of the institution. This is particularly important at this time with the present strong tendency of invested funds to yield a reduced income, such income being the main source of support to the institution. The unrestricted gifts to the cultural purposes fund amounted to $\$ 7100.00$ from 308 individuals. Restricted gifts are as follows: The response to an appeal sent out late in 1938 to individuals outside of New England for a hurricane damage rehabilitation fund yielded $\$ 2909.70$ from 143 individuals. These returns came from all over the United States outside of the hurricane area, as well as from Canada, Great Britain, and the Philippine Islands. Supplementing a grant of $\$ 1500.00$ to Dr. Raup from the Milton Fund of Harvard University received last year to enable him to undertake a field trip to the remote South Nahanni River region in northwestern Canada, two additional grants were received for the same purpose, $\$ 400.00$ from the Science Fund of the American Academy of Arts and Sciences in Boston, and $\$ 300.00$ from the Bache Fund of the National Academy of Sciences in Washington. Final payment amounting to $\$ 187.50$ was received from the Penrose Fund grant, American Philosophical Society, Philadelphia, in connection with the Bornean Eugenia project which was completed early in the year. An anor ymous friend of the Arboretum generously provided $\$ 1000.00$ which enabled us to send Dr. Croizat to Paris for several months during the winter season his major task while there being to segregate important sets of duplicates from historical collections to enrich our herbarium. The same anonymous supporter also provided $\$ 125.00$ for special photographic equipment needed to make time lapse pictures. Two friends of the institution generously provided $\$ 700.00$ to be used in support of field work in China and to help provide a scholarship for Miss Luetta Chen, a graduate student in botany in Radcliffe College. The Massachusetts Society for the Promotion of Agriculture granted $\$ 500.00$ for use in continuation of horticultural-botanical exploration in China. A member of the visiting committee generously continued his annual gift of $\$ 500.00$ 
for the care of conifers. And finally $\$ 500.00$ was received from the National Research Council to support special work in genetics under the direction of Dr. Sax. No actual additions were made to the general endowment fund, other than those annually made in connection with certain restrictions appertaining to two special funds, although notice has been received of a bequest of $\$ 25,000.00$ from the estate of the late Miss Grace R. Edwards of Boston.

Buildings and grounds.- Normal attention has been given to all buildings, minor repairs having been made as needed. The same statement applies to the grounds, modified, of course, by the enormous amount of rehabilitation work required as a result of the tremendous hurricane damage, September 21, 1938. This was the greatest single catastrophe that has happened to the plantings in the Arboretum since its establishment in 1872. Approximately 1500 trees were destroyed, although fortunately the actual loss in named species and varieties was very small. The very diversified topography of the grounds protected many of the plantings, excessive damage being largely confined to the exposed parts of Peters Hill, Hemlock Hill, Bussey Hill, and the slope immediately back of the Administration building, with a relatively narrow strip extending through the pinetum opposite the low land between Peters Hill and Hemlock Hill. Details of the storm damage are given in the Bulletin of Popular Information. IV. 6: 71-74. October 7, 1938.

As a result of this major catastrophe the entire grounds staff concentrated on the removal of fallen trees and in the general rehabilitation work required through the fall and winter months. By May, the débris was largely cleared, leaving the grounds in a distinctly presentable condition for the great spring displays. While many stumps remain to be removed, some fallen trees still remain in the forested tracts, and much pruning must still be done, this can be taken care of during the coming winter season as a part of the normal program. By judicious planning, and the utilization of funds drawn from the credit balance of the institution, supplemented by gifts from supporters of the Arboretum, it has been possible for us to consummate the major part of the rehabilitation work with our own staff, retaining throughout the winter months those employees who are normally dropped during the usually slack winter season. In preparation for the fall planting in the heavily devastated areas, 625 two to six feet stock of hemlock, white pine and red pine have been acquired for the necessary mass and screen plantings.

The great amount of extra work involved a number of adjustments and required a certain amount of innovation such as increased motorized equipment in the form of a tractor, a low wagon for moving logs and 
stumps, a power driven portable cross-cut saw, and other minor equipment. With the tractor a cutter bar attachment was acquired which enabled us to accomplish the necessary grass cutting with our own staff at a considerable financial saving, as formerly it was necessary to arrange with a contractor to have this work done. As a further measure of economy a standard gasoline storage tank and pump was installed near the propagating grounds for the official motorized equipment of the institution.

The work on the detailed mapping of the grounds has been continued. Fifty-six of the section maps have been retraced and the final prints made. The plant locations on the entire series of eighty-two maps have been transferred to the card catalogue. This work has involved hundreds of changes in nomenclature, as mistakes in names have accumulated over a long period of years. To facilitate this work Mr. Palmer continued his task of preparing many thousands of botanical specimens from the named and unnamed shrubs and trees in flower and in fruit, this material being essential to a proper identification of many of the species involved in our serious attempt to modernizẻ and correct the plant labels. New metal labels have been attached to all plants where changes in name have been made, and in the following winter the corresponding display labels will be prepared and attached.

The poison ivy eradication campaign, initiated last year, has been continued with marked results in the reduction of this ornamental, yet at the same time, distinctly noxious plant. In the Walter Street nursery development about a half acre has been planted and $21 / 2$ acres have been ploughed, fertilized and sown to a cover crop in preparation for planting development next season.

Through the cordial cooperation and support of the Park Department, in spite of the fact that the Park Department itself was burdened with a tremendous fall and winter task of its own, the entire boundary fence of the Arboretum was renovated, involving rather extensive replacements in those sections badly damaged by falling trees. About 3000 feet of permanent tar-macadam sidewalk was also constructed along both sides of the road leading to Bussey Hill.

Horticulture.- In the fall of 1938 only 38 additional plants were placed in the permanent plantings of the Arboretum, because of the great amount of hurricane damage rehabilitation work that had to be done and which continued through the fall and winter months. In the spring 470 additional plants were placed, making a total of 508 for the year. Many of these represent species and varieties new to the living 
collections. During the year 2423 living plants were received at the nursery from various institutions in the United States and from nine foreign countries. At the same time 121 scions and cuttings were received as well as 2225 packages of seeds; this material came from various sources in fourteen different countries. The largest single accession was one shipment of about 2000 packages of seeds from the T. T. Yü Expedition to Yunnan, China, under the auspices of the Fan Memorial Institute of Biology in Peiping, the field work being in part supported by a grant from the Arnold Arboretum.

In the plant and seed distribution field 1173 living plants were sent to numerous correspondents of the Arboretum, supplemented by 691 scions and cuttings, recipients residing in ten different countries. About 12,000 packets of seeds from the Yü Yunnan collections were distributed to about 40 correspondents of the Arboretum all over the world. The bulk of the seeds of herbaceous species was transmitted to the Massachusetts Horticultural Society for distribution to its members and to others who might be interested. Supplementing this special distribution, 555 packets of seeds from Arboretum sources were sent to numerous correspondents in the United States and fifteen foreign countries.

Within the horticultural field approximately fifty illustrated lectures were given to audiences in New England and as far afield as Illinois, Wisconsin, and Virginia. Approximately 2000 letters were written in response to inquiries regarding woody plants. Some work has been continued on the proposed new edition of Standardized Plant Names. The Bulletin of Popular Information list now stands at about 1600, the usual number of issues having been prepared and issued during the year.

Cytogenetic Laboratory.- The investigations in experimental cytology have been devoted largely to a study of the effects of X-rays on chromosome alterations. Such work is of interest in relation to speciation, since it has been shown that speciation often is associated with structural changes in the chromosomes. It has been found that the types and frequencies of chromosome alterations induced by X-rays vary at different stages in the nuclear cycle. The frequency of aberrations increases exponentially with dosage, and is dependent on the time-intensity factor and the temperature at the time of irradiation. An analysis of spontaneous chromosome alterations by Mr. Giles has shown that these changes resemble those induced by $\mathrm{X}$-rays, although the spontaneous clianges are not caused by natural radiation. The X-ray work has been supported, in part, by grants from the National Research Council Committee on Radiation during the past two years. 
Previous studies have shown that extreme temperature changes result in chromosome doubling in plants. Mr. Giles has shown that temporary periods of drouth may be an even more important factor than temperature changes in the production of polyploidy in nature.

The improvement of ornamental plants by genetic methods has been conducted along several different lines; (1) X-ray treatment to produce mutation and gross chromosome changes, (2) the production of polyploids with colchicine, (3) artificial crossing of species and varieties, and (4) the utilization of natural hybridization.

Seedlings of about 30 species of ornamental plants were subjected to X-ray treatment. Each lot consisted of about 50 plants, arranged so that a variable dosage was given to produce a wide range of effects. The resulting plants, now in the cold-frames, show great differences in growth rate, but other characters show little change so far.

Controlled crosses between species have been continued and several hundred species hybrids are now growing in the nursery. These include apples, cherries, roses, lilacs, azaleas, and magnolias.

Species of apples and cherries are largely self-sterile, and where single specimens of a species are surrounded by other species of the same genus, the seeds produced must result from crosses between species. This natural hybridization provides large numbers of hybrids for the selection of superior types. The more ample nursery space now available has been utilized in growing many of these natural hybrids. There are now about 5000 of these apple seedlings and several hundred cherry seedlings in the nursery. The seedlings from most of the parent trees are extremely variable. The results of this work are being analysed by Mr. Skirm.

The colchicine technique is being used to produce polyploid forms of ornamental trees and shrubs, with good results in certain species. The polyploids should be somewhat sturdier and should flower later than the diploid forms.

The artificial culturing of young embryos often permits the production of hybrids which can not otherwise be obtained. This technique is being used successfully in crosses between species of lilies by Mr. Skirm.

The Bussey institution has been used during the summer months by staff members, students, and occasional visiting investigators working in cytology and genetics. Ten men have been at the Bussey for full or part time work during the past summer.

Wood Anatomy.- During the last year the collection of woods, which was transferred from the Arnold Arboretum, has been incorporated with those previously housed in the Biological Laboratories. The 
combined collections have been rearranged, catalogued, and classified by families. In addition, considerable progress has been made in sectioning the woods of selected families, particularly the Juglandaceae, Olacaceae, Santalaceae, Sapindaceae, Rutaceae, Anacardiaceae, Meliaceae, Burseraceae, and Icacinaceae. More than 3500 microscopic slides have been added to the collection during the last twelve months, making a total of more than 20,000 slides of gymnosperms and angiosperms.

Professor Bailey and Mr. Howard are making an extensive investigation of the stem, node, petiole, and floral organs of the Icacinaceae with the object of determining to what extent the salient lines of structural specialization of the stem are correlated with those of the flower and leaf. Dr. Dahl is cooperating in the study of the pollen of this family. Professor Wetmore and Mr. Heimsch have completed and published a detailed study of the comparative anatomy of the woods of the Juglandaceae. Their findings regarding the relationships of the various genera are on the whole in close agreement with those of Manning based upon investigations of the inflorescences and flowers of this family. Mr. Taylor has prepared for publication an investigation of the relationships of the parietalean families based on the anatomy of the secondary xylem. Mr. Heimsch is continuing his survey of the woods of the Geraniales and Sapindales in an endeavor to correlate the results with current taxonomic concepts of the order.

Plant Pathology.- The extension services of the Arboretum's laboratory of plant pathology have been manifold during the year. Inquiries for advice and specimens for diagnosis have been received from as far west as the Pacific coast and as far south as the Carolinas, from Europe and from various parts of Canada. As part of this work a visit of several days was made to the Province of Quebec as guest of its Department of Lands and Forests to advise on a program of investigation in forest pathology. Interest in the program of eradication of the Dutch elm disease has been actively maintained. In that connection, the Arboretum has been represented at Washington twice during the year in appeals to the federal government for maintenance of the undertaking.

Valuable additions have been made to the herbarium, especially of the rust fungi of trees. Some have come as contributions and some from collections made by staff members. Among the latter special mention should be made of materials obtained on a collecting trip to southern Mexico in November and December. The field work there was rendered all the more fruitful because of the generous assistance afforded by the 
Mexican forest service. In addition to tree infecting fungi found in Mexico, abundant gatherings were secured of the cones, foliage and wood of a fir from the State of Oaxaca, and from these it has been possible to complete the description of an important timber tree (Abies Hickeli). From fir specimens collected the previous year in Guatemala, a new species ( $A$. guatemalensis Rehder) has at the same time been published. Record is also made of the discovery in Maine of Chrysomyxa Empetri on spruce, a rust on that host not before known for the United States, and heretofore known only, as the result of Arboretum research, from the Province of Quebec. Considerable time has been spent in overhauling the collections of wood-destroying fungi. This has comprised re-labelling, boxing and sorting specimens. So far about 1000 duplicates have been turned over to the Farlow Herbarium and 300 sent to the Bureau of Plant Industry at Washington.

Research activities have covered a number of subjects. Mr. E. V. Seeler has materially advanced his investigation of a wilt disease of Gleditsia, not before known until found a few years ago on $G$. japonica in the Arboretum plantings. The causative agent has been established and a preliminary note published. Of especial interest is the fact that Mr. Seeler has found the native Gleditsia on Nantucket Island to be infected with the same causal organism, though the manifestations on the native hosts are different and less severe than on the introduced species. The fungus has been reported from rather widely separated regions in America, but without previous recognition of its pathogenicity.

Work is continuing on a serious bark disease of the flowering dogwood. It was first noted on Long Island, but a case was found last July at Amherst, Massachusetts.

Considerable progress has been made in the studies of the rust fungi of the conifers and of the Pomaceae. Most important of the publications issued are monographic treatments of the biology, taxonomy and geographical distribution of the genus Uredinopsis. These rusts are all heteroecious, having as their alternate hosts firs (Abies) on the one hand and various ferns of the Polypodiaceae and Osmundaceae on the other. Representatives occur in all of the continents except Australia. Several new species are described and accounts given of various new life history researches. A detailed study of the genus reveals many pronounced morphological diversities exhibited by the spores. According to the species they are smooth, uniformly warted or spinose, cogged along two opposite longitudinal lines or appendaged. Perhaps the most remarkable is a newly described type with capsulated spores found in two species, one from Guatemala and the other from Eastern Asia. It was incidental 
to the tracing of these rusts to the southernmost limits of Abies that knowledge of the two firs referred to above was obtained.

The Herbarium.- The number of mounted specimens actually distributed into the herbarium was unusually small, only 5218 sheets, bringing the total to 484,942 specimens. During the year, however, in excess of 38,000 additional sheets were mounted, mostly from collections under study and hence not yet ready for herbarium distribution. The year has been characterized by an unusually large number of important accessions, approximating 111,500 specimens, not including duplicates. The numerous collections received vastly exceed in number of specimens any single year's accessions in the entire history of the institution. Nearly half of these, about 53,000 specimens are from Asia, about 38,600 being from China alone. Important Chinese accessions include the Lingnan University material from Kwangsi, Kwangtung, and Hainan, the Yunnan collections of T. T. Yü and important Hopei collections from the Fan Memorial Institute of Biology, and Szechuan material from Nanking University, Chengtu. Approximately 3000 Indian plants were received from the Royal Botanic Garden, Calcutta, extensive additional collections of Burma plants from Dr. Dickason of Judson College, Rangoon, and important exchanges from the Botanic Garden, Singapore, and the Bureau of Science, Manila. The outstandingly important collection from the Old World tropics is the enormous L. J. Brass collection from the previously unexplored Wilhelmina Mountains, Netherlands New Guinea, assembled in connection with the third Richard Archbold expedition to New Guinea. This collection contains approximately 5500 numbers perhaps averaging 5 duplicates to a number. From Asiatic Russia about 2000 specimens were received from the Principal Botanic Garden at Leningrad. Approximately 14,000 specimens were received from various parts of North and South America including 700 Skutch plants from Costa Rica, 800 Gentle plants from Honduras, 1800 Mexican plants from the collections of Hinton and Matuda, and about 4500 specimens from the Thompson collections in British Columbia. Especially important exchanges include 11,480 miscellaneous duplicates from all parts of the world received from the Botanic Garden, Geneva, Switzerland, about 18,000 specimens from the Paris Museum of Natural History, largely from China and Indo-China but including very important material from other parts of the world, the special Koehne Lythraceae herbarium from the Berlin Botanic Garden, and about 750 South American specimens, largely from the historical Poeppig collection from the Vienna Museum of Natural History. 
In continuation of exchanges 50,017 duplicates were distributed to various American and foreign institutions; 14,470 specimens of herbaceous plants were transmitted to the Gray Herbarium, 1931 orchid specimens to the Ames Orchid Herbarium at the Botanical Museum, and 1205 specimens of cellular cryptogams to the Farlow Herbarium.

Forty-five loans were sent to 19 different institutions in America, Europe and Asia, approximating 4000 mounted sheets for study, while 52 loans with about 8511 mounted sheets were received from 23 institutions in the United States, Canada, Netherlands, France, Germany, England, Scotland and Sweden for the use of our own staff members.

The collection of negatives representing types and critical specimens has been increased by 228 , the total now being 3951 negatives. The current card catalogue of references to names and descriptions of new species and of illustrations was increased by 3790 cards, now standing at 121,177 entries.

Work on segregating species in large genera in colored genus covers for specific geographic areas has been continued, and in addition, species covers are being inserted for convenience in consulting the material. It is estimated that between 20,000 and 25,000 additional typed or clipped entries have been inserted into the herbarium, these covering not only original descriptions but also redescriptions, critical notes, etc.; numerous illustrations are also included. Many additional data of this type are prepared and are now being arranged for distribution.

Perhaps the most important item in reference to the efficient prosecution of herbarium work has been the clipping and alphabetizing, in loose leaf ledger form, of all the entries in Index Kewensis and its nine supplements. The work has been done in such a manner that future additions may be made for many years without seriously breaking sequences, while the entries for all large and medium sized genera are left "hanging" so that by the insertion of new sheets, as necessary, additions can be made indefinitely. The data are arranged in six large binders, thus bringing together in a single sequence all the entries under each genus. The usefulness of this is obvious when it is realized that in extreme cases in examining Index Kewensis, one must, or should, search in fifteen different places to be sure that one is not overlooking a name and reference.

Work by staff members has continued on the groups, as indicated, in the last report. Professor Rehder has completed his manuscript for a thorough revision of his Manual of Cultivated Trees and Shrubs which is to be published in 1940, and has given much attention to nomenclatural problems. Another activity on his part has been the correcting of the 
identifications on the great collection of Arnold Arboretum cultivated plants assembled by Mr. Palmer during the past two years, this being a part of our program to modernize and correct labels on all species and varieties now cultivated as far as this is possible. Dr. Johnston spent two months in field work in Coahuila, Zacatecas, San Luis Potosi, and Chihuahua, Mexico, in association with Dr. Forrest Shreve of the Desert Laboratory of the Carnegie Institution. The objective was a cooperative ecological and botanical survey of the desert areas of northern Mexico. Over 1000 numbers, with about 3000 specimens of herbarium material were prepared, the collection having been studied during the past winter. In addition to this work he has studied and reported on about 1200 numbers of plants from the Argentine and Chilean collections of Barros, Parodi, and Cabrera, and has reported on about 1250 specimens of Boraginaceae sent to him by various correspondents for identification. As a result of his activities in the last two fields 2422 mounted specimens were added to the reference collections at the Gray Herbarium. He has also supervised the work of Carlos Muñoz, Guggenheim Fellow from Chile, working at the Gray Herbarium. Dr. Kobuski, in addition to his general herbarium and editorial work has continued his studies on Eurya and Jasminum. Dr. Allen is continuing her general studies on Old World Lauraceae. In association with Miss Freeman, I have completed a critical revision of the Old World species of Microtropis, while with Dr. Perry general work on the L. J. Brass collections from the Fly River Region, New Guinea (Second Richard Archbold Expedition) has been initiated. Considerable work has also been accomplished on various Chinese, Indo-Chinese, and Burmese collections submitted to me for identification and report. Much attention has also been given to the problem of completing a supplement to the Bibliography of Polynesian Botany, about 350 additional entries having been completed and prepared for printing. The plan is to carry this through to the end of December, 1939, and then publish the results. Dr. Raup was in residence during the past summer at the Harvard Forest, Petersham, engaged in an intensive study of land ownership, and use of all parcels now forming the Harvard Forest from the period of first settlement until the present time. In the latter part of the year he completed his plans for his eighth trip to northern Canada, his objective this time being the remote South Nahanni River region in the extreme northwest. This trip was made possible by a grant from the Milton Fund of Harvard University, supplemented by smaller grants from the American Academy of Arts and Sciences, the National Academy of Sciences, and the Arnold Arboretum. Dr. Jones completed and published his revision 
of the North American species of Sorbus, completed and published his flora of Mount Rainier, has practically completed his revision of the genus Symphoricarpus and has accomplished much work on the manuscript of his flora of the Pacific Northwest. Dr. Croizat was able to spend several months in Paris during the winter, through the generosity of an anonymous friend of the Arboretum. Here he studied numerous euphorbiaceous types, and through arrangements made by Dr. H. Humbert, was enabled to segregate from the vast store of duplicate specimens there, approximately 18,000 specimens which were received at the Arboretum before the end of the year. He has continued his work on the classification of the Euphorbiaceae, and in association with Mr. Hara, a Japanese botanist spending the year at the Gray Herbarium, has initiated a study of the Formosan species based, in part, on actual types borrowed from Japanese institutions. Miss Luetta Chen, part time assistant, has continued work on the Chinese species of Bauhinia, and has undertaken a revision of the eastern Asiatic species of Ormosia. Mr. Russell Seibert, another part time assistant, has worked intensively on the Central American species of Bignoniaceae. Prof. F. P. Metcalf of Lingnan University has reported at the Arboretum, planning to spend much of the coming year here working on the Chinese flora.

In further development of cooperative botanical-horticultural explorations additional grants have been made to the Fan Memorial Institute of Biology, Peiping, for field work in Yunnan, to Nanking University, Chengtu, for work in Szechuan, to J. W. Thompson, Seattle, for field work in British Columbia, to Robert Virot, Noumea, for work in New Caledonia, E. Fénix, for work in the Philippines, to Judson College, Rangoon, Burma, to support Dr. Dickason's field work, and to the University of Michigan in partial support of Dr. Eyma's field work in Netherlands New Guinea. The grants to Chinese institutions were made possible through a special gift received from the Massachusetts Society for the Promotion of Agriculture for horticultural-botanical work in China.

The Library.- At the end of the fiscal year the library comprised 44,123 bound, and several hundred unbound volumes, 12,469 pamphlets, 18,444 photographs, 3000 slides, and several thousand nursery catalogues. Additions during the year include 566 bound volumes, 166 pamphlets, and 266 photographs, among which were 32 from L. J. Brass, taken on the Archbold expedition to New Guinea, 70 of hurricane damage, 14 from A. B. Morse Co., Michigan, and 12 of prominent scientists from A. E. Marr. A total of 10,858 cards were distributed in the various 
indices and 1791 slips were filed in preparation for supplements to the printed Author and Subject catalogues of the library, making the number now available for publication 28,000. The number of books bound was 223, while 136 were put into pamphlet binders and a large number tied in manila covers. Seven new periodicals were acquired among them being a nearly complete set of the Journal of the Straits Branch of the Royal Asiatic Society and the rare Journal des roses, 1877-1914. A number of important atlases have been acquired including the first volume of the Russian "Bolshoi Atlas Mira." More than 200 volumes have gone out as inter-library and special loans; photostats have been made and references checked and copied. The demand for photographs continues, 379 having been sold during the year. Two copies of the Catalogue of the Library of the Arnold Arboretum, Vol. 1-3, and 6964 slips for copying were sent to the University Library, in order that the entries might appear in its union catalogue. Visitors from many states and eleven foreign countries registered in the library during the year.

The Atkins Institution of the Arnold Arboretum, Soledad, Cienfuegos, Cuba.- From the garden standpoint the most important item in the past year's accomplishments has been the consummation of an agreement with the Soledad Sugar Company as to the ultimate area of the garden and the final fixing of the boundary lines. An actual survey was made in February, 1939, the area definitely assigned to the garden being 221.63 acres. It is now possible to make plans for the permanent location of study groups particularly with view to the placing of those species needing relatively little moisture on the outlying lands thereby avoiding the necessity for the extension of the present water lines.

The construction of a new house with dormitory facilities for eight individuals and two private rooms that will accommodate four more will make a much greater use of the garden possible. Casa Catalina, a permanent concrete building constructed in part at the expense of Mrs. Edwin F. Atkins and in part through an anonymous gift, is located on the brow of the hill above Harvard House, overlooking the garden and the surrounding valley to the mountains beyond. Construction was completed in January, 1939. The provision of these facilities for housing additional investigators will enable us to invite representatives of other institutions in the United States and elsewhere to take advantage of the research facilities available at the Atkins Institution and thus extend its influence and productivity.

During the early spring most of the older hurricane damaged trees in the old garden were removed. Here are being transplanted numerous 
palms from other parts of the garden with view to developing this section into a special palm garden. Additional plantings have been made in the extensive new succulent garden, and in the seburuco section, reserved for native vegetation. In the latter much thinning of the various weed trees has been accomplished, as well as the removal of many of the lianas and coarse grasses that seriously interfered with the development of the arborescent vegetation. This interesting section has been made much more accessible by the improvement of roads and the opening of trails. We are greatly indebted to several Cuban botanists for many new plants. Brother Léon and Señor Carrabia, collaborators on the staff of the institution, have generously supplied many native Cuban ferns for these plantings.

As a result of the improved communications, as noted in a previous report, the number of visitors increases annually. Now that the garden can be reached over really good automobile roads, located as it is just off the main Havana-Cienfuegos highway, several changes have been made in the driveways within the grounds to facilitate automobile traffic, and attention will soon have to be given to bridge and culvert construction in the near future.

As a part of its service to Cuban horticulture and botany, 442 living plants, 113 packages of cuttings, and 456 packages of seeds were distributed during the year, while 67 packages of cuttings and 556 packages of seeds were received.

During the year Professors Bailey and Needham of Cornell University have made use of the facilities available at the Atkins Institution in connection with their research problems. Brother Marie Victorin of the University of Montreal visited the Garden twice in company with Brother León, one of our collaborators, and a number of Cuban officials took advantage of the facilities offered. The usual number of Harvard University graduate students spent the summer at the Harvard House laboratory. A complete report on the scientific activities of the Institution since Harvard House was constructed, and a general résumé of Garden history since its inception thirty-five years ago, is in process of preparation. One of the objectives in the preparation of this report is to call attention to the now amplified facilities available at the Atkins Institution for those interested in biological research in the tropics.

Publications.- In addition to issuing the usual numbers of the Journal and of the Bulletin of Popular Information a number of technical, semi-technical, and popular papers were published by staff members in standard serials issued elsewhere, as indicated in the 
appended bibliography of publications by staff members. One number of the Contributions was issued, an important paper by Dr. Faull on the genus Uredinopsis. A very useful manual on the technique of preparing and handling of herbarium specimens, prepared by Dr. Johnston, was also issued during the year, it being intended primarily for the use of correspondents of the Arboretum engaged in field work.

\section{Bibliography of the Published Writings of the Staff and Students July 1, 1938 - June 30, 1939}

AbBe, L. B. \& Crafts, A. S. Phloem of white pine and other coniferous species. Bot. Gaz. 100:695-722, 47 fig. 1939.

Alten, C. K. Studies in the Lauraceae. II. Some critical and new species of Cinnamomum and Neocinnamomum. Jour. Arnold Arb. 20: 44-63. 1939.

Bailey, I. W. The microfibrillar and microcapillary structure of the cell wall. Bull. Torrey Bot. Club 66: 201-213, 11 fig. 1939.

Barghoorn, E. S., Jr. \& Bailey, I. W. The occurrence of Cedrus in the auriferous gravels of California. Am. Jour. Bot. 25:641-647, 19 fig. 1938.

Crafts, A. S. The relation between structure and function of the phloem. Am. Jour. Bot. 26: 172-177, 5 fig. 1939.

Croizat, L. From Arboretum to the nursery. Am. Nurseryman 68(8): 3-4. 1938.

Glands of Euphorbiaceae and of Euphorbia. Chron. Bot. 4: 512-514. 1938 .

1938.

Une nouvelle sous-famille des Olacacées au Bresil. Bull. Soc. Bot. France 86: 5-7. 1939.

Faull, J. H. The biology of rusts of the genus Uredinopsis. Jour. Arnold Arb. 19: 402-436. 1938.

- The Dutch elm disease situation in the United States at the close of 1938. Arnold Arb. Bull. Pop. Inf. IV. 6: 75-78, pl. 15. 1938.

Taxonomy and geographical distribution of the genus Uredinopsis. Contrib. Arnold Arb. 11: 1-120, pl. 1-6. 1938.

- A review and extension of our knowledge of Calyptospora Goeppertiana Kuehn. Jour. Arnold Arb. 20: 104-113. 1939.

Giles, N. The effect of dehydration on microsporogenesis in Tradescantia. Am. Jour. Bot. 26:334-339. 1939.

Johnston, I. M. The species of Sisyrinchium in Uruguay, Paraguay and Brazil. Jour. Arnold Arb. 19: 376-401. 1938.

New or noteworthy plants from temperate South America. Jour. Arnold Arb. 19: 248-263. 1938.

234-240. 1939. 
Johnston, I. M. The preparation of botanical specimens for the herbarium. Jamaica Plain, Mass. 1939. 1-33, 5 pl. 1939.

New Fuchsias from southern Peru. Jour. Arnold Arb. 20: 241-244. 1939.

Jones, G. N. The flowering plants and ferns of Mount Rainier. Univ. Wash. Publ. Biol. 7: 1-192, pl. 1-9. 1938.

359. 1938.

Leafl. West. Bot. 2: 105-108. 1938.

A synopsis of the North American species of Sorbus. Jour. Arnold Arb. 20: 1-43, pl. 226-227. 1939.

Koвuski, C. E. New and noteworthy species of Asiatic Jasminum. Jour. Arnold Arb. 20: 64-72. 1939.

Lotт, H. J. Nomenclatural notes on Hypericum. Jour. Arnold Arb. 19: 279-281. 1938.

Merrill, E. D. Biographical memoir of Nathaniel Lord Britton. Nat. Acad. Sci. Biogr. Mem. 19: 147-202, portr. 1938.

- A critical consideration of Houttuyn's new genera and new species of plants, 1773-1783. Jour. Arnold Arb. 19: 291-375. 1938.

On Houttuyn's overlooked binomials for native or introduced plants in eastern North America. Rhodora 40: 288-293, pl. 495. 1938.Repr. Contrib. Gray Herb. Harvard Univ. 122: 288-293, pl. 495.1938.

— Additional notes on Houttuyn's binomials. Jour. Arnold Arb. $20: 264-268.1939$.

Index Kewensis in improved loose leaf ledger form. Arnold Arb. Bull. Pop. Inf. Iv. 7: 37-40, pl. 6. 1939.

A new species of Byttneria from Mangareva. Bishop Mus. Occ. Papers 14: 313-315, 1 fig. 1939.

63-92. New Sumatran plants. IV. Pap. Michigan Acad. Sci. 24(1): 63-92. 1938 (1939).

Recent accessions at the Arnold Arboretum. Harvard Alumni Bull. 41: 1002-1004, 1 fig. 1939.

Two new species of opposite-leaved Ilex from Borneo. Jour. Arnold Arb. 20: 222-224. 1939.

\& Metcalf, F. P. A new species of Boottia from Hainan. Lingnan Sci. Jour. 17: 567-570, pl. 24-25. 1938.

\& PERry, L. M. Additional notes on Chinese Myrtaceae. Jour.

Arnold Arb. 20: 102-103. 1939.

\& Perry, L. M. On the Brass collections of Pandanaceae from New Guinea. Jour. Arnold Arb. 20: 139-186, 2 pl. 1939.

_ \& Perry, L. M. The Myrtaceae of China. Jour. Arnold Arb. 19: 191-247. 1938.

Muñoz, C. Dos especies nuevas para el norte de Chile. Jour. Arnold Arb. 20: 245-249, 2 pl. 1939.

Palmer, E. J. \& Steyermark, J. A. Additions, corrections, and revisions to the "Annotated catalogue of the flowering plants of Missouri." Ann. Missouri Bot. Gard. 25: 775-794. 1938. 
Palmer, E. J. \& Steyermark, J. A. New varieties and forms from Missouri. Ann. Missouri Bot. Gard. 25: 769-773. 1938.

Perry, L. M. Gonolobus within the Gray's manual range. Rhodora 40: 281-287, pl. 494. 1938; Repr. Contrib. Gray Herb. Harvard Univ. 122: 281-287, pl. 494.1938.

Raup, H. M. The North meadow. Arnold Arb. Bull. Pop. Inf. Iv. 7: 21-24, pl.3. 1939.

Rehder, A. Bibliographical note on "Ehrh. Plantag." Jour. Arnold Arb. 20: 137.1939.

- New species, varieties and combinations from the collections of the Arnold Arboretum. Jour. Arnold Arb. 19:264-278. 1938; 20: 85-101. 1939.

- Proposed amendments to the International rules of botanical nomenclature. Jour. Arnold Arb. 20: 269-279. 1939.

- Palmer, E. J. \& Croizat, L. Seven binomials proposed as nomina ambigua. Jour. Arnold Arb. 19: 282-290. 1938.

SAx, H. J. The relation between stomata counts and chromosome numbers. Jour. Arnold Arb. 19: 437-441. 1938.

SAx, K. Chromosome aberrations induced by x-rays. Genetics 23: 494-516. 1939.

The time factor in $\mathrm{x}$-ray production of chromosome aberrations. Proc. Nat. Acad. 25: 225-233. 1939.

- \& Mather, K. An x-ray analysis of progressive chromosome splitting. Jour. Genetics 37: 483-490. 1939.

Seeler, E. V., JR. Thyronectria denigrata (Winter) Seaver, the cause of disease in Gleditsia. Jour. Arnold Arb. 20:114-115. 1939.

Seibert, R. J. \& Woodson, R. E., Jr. Contributions toward a flora of Panama. II. Miscellaneous collections during 1936-1938. Ann. Missouri Bot. Gard. 25: 823-840. 1938.

WALkER, R. I. The effect of colchicine on the developing embryo sac of Tradescantia paludosa. Jour. Arnold Arb. 19:442-445, pl. 224-225. 1938.

Wyman, D. Chiefs of the mockorange tribe. Real Gardening 1(12): 59-65, 4 fig. 1939.

5-13, 2 pl. 1938.

evergreens that never grow tall. Real Gardening 1(4): Clipped hedges for fall planting. House Beautiful 80(10): 88, 122-126. 1938.

- Cytisus for New England. Arnold Arb. Bull. Pop. Inf. Iv. 6: 59-62, pl. 11. 1938.

- Flowering crabapples for spring and fall. Arnold Arb. Bull. Pop. Inf. IV. 7: 25-32, pl. 4-5. 1939.

The hedge demonstration plot at the Arnold Arboretum. Arnold Arb. Bull. Pop. Inf. Iv. 6: 79-86, pl. 16. 1938.

Hedges, screens \& windbreaks; their uses, selection and care.

New York; London. 1938. i-xviii, 1-249, map and plates. 1938.

The hurricane. Arborist's News 3(11): 1-4. 1938. 
Wyman, D. Hurricane damage at the Arboretum. Arnold Arb. Bull. Pop. Inf. iv. 6: 71-74, pl. 14. 1938.

Hurricane damage in New England. Gard. Chron. 104: 355-356, 1 fig. 1938. 1938 Lilac named for Miss Preston. Horticulture 16:310, 1 fig. Lilac species for landscape planting. Am. Nurseryman 68(12): 3-5, 3 fig. 1938.

- Lilacs at Harvard's Arnold Arboretum. Parks \& Recreation 22: 519-522, 3 fig. 1939.

- Narrow upright trees in the Arnold Arboretum. Arnold Arb. Bull. Pop. Inf. iv. 6: 63-67, pl. 12-13. 1938.

- Natural screens and windbreaks. Real Gardening 1(10): 78-85, 4 fig. 1939.

Pop. Inf. Iv. 7: 17-20. 1939

Mag. 17: 196-204. 1938.

- Oriental flowering crabapples. House \& Garden 73(10) : 29-31, 90, 8 fig. 1938.

1939.

- Out-of-the-ordinary hedges. Nat. Nurseryman 47(5):13.

The park arboretum. Am. Nurseryman 68(10):3-5. 1938.Parks \& Recreation 22: 96-99. 1938

- The past winter at the Arboretum. Arnold Arb. Bull. Pop. Inf. IV. $7: 1-4.1939$.

Shrubs for that shady corner. Real Gardening 1(7): 58-64, 3 fig. 1938.

1939.

1939.

- Summer-blooming vines. Gard. Chron. Am. 43: 184-186, 1 fig.

1939.

pl. 2. 1939

1 fig. 1938.

This hesitant spring. Arnold Arb. Bull. Pop. Inf. iv. 7: 13-16.

$$
\text { - Twelve shrubs to provide a succession of bloom in the garden }
$$
throughout the year. House Beautiful 81(6): 61, 73-76. 1939.

1939.

- Two months of azaleas. Gard. Chron. Am. 43:70-71, 3 fig.

Viburnums for year round beauty. House \& Garden 74(4):

60-61, 74, 87, 11 fig. 1939.

Why autumn color? Real Gardening 1(6):66-72. 1938.

1939.

Wyman comments on lilacs. Nat. Nurseryman $47(6): 4,8$.

E. D. Merrill, Director 


\section{Staff of the Arnold Arboretum, 1938-39}

Elmer Drew Merrill, S.D., LL.D., Arnold Professor of Botany and Director.

John George Jack, Assistant Professor of Dendrology, Emeritus.

Alfred Rehder, A.M., Associate Professor of Dendrology and Curator of the Herbarium.

Joseph Horace Faull, Ph.D., Professor of Forest Pathology.

Irving Widmer Bailey, S.D., Professor of Plant Anatomy.

Karl Sax, Ph.D., Professor of Cytology.

Ivan Murray Johnston, Ph.D., Associate Professor of Botany.

Clarence Emmeren Kobuski, Ph.D., Assistant Curator of the Herbarium.

Donald Wyman, Ph.D., Horticulturist.

Ernest Jesse Palmer, Collector and Research Assistant.

Caroline Kathryn Allen, Ph.D., Assistant in the Herbarium.

Hugh M. Raup, Ph.D., Assistant Professor of Plant Ecology.

Lily M. Perry, Ph.D., Technical Assistant.

Leon Croizat, J.D., Technical Assistant.

Ethelyn Maria Tucker, Librarian.

Susan Delano McKelvey, Research Assistant.

Constance Mansfield Gilman, Business Secretary.

Louis Victor Schmitt, Superintendent.

William Henry Judd, Propagator. 


\section{$2 \mathrm{BHL}$ Biodiversity Heritage Library}

1939. "The Arnold Arboretum during the fiscal year ended June 30, 1939."

Journal of the Arnold Arboretum 20, 446-463. https://doi.org/10.5962/p.325794.

View This Item Online: $\underline{\text { https://www.biodiversitylibrary.org/item/33596 }}$

DOI: https://doi.org/10.5962/p.325794

Permalink: https://www.biodiversitylibrary.org/partpdf/325794

\section{Holding Institution}

Missouri Botanical Garden, Peter H. Raven Library

\section{Sponsored by}

Missouri Botanical Garden

\section{Copyright \& Reuse}

Copyright Status: In copyright. Digitized with the permission of the rights holder.

Rights Holder: Arnold Arboretum of Harvard University

License: http://creativecommons.org/licenses/by-nc-sa/3.0/

Rights: https://biodiversitylibrary.org/permissions

This document was created from content at the Biodiversity Heritage Library, the world's largest open access digital library for biodiversity literature and archives. Visit BHL at https://www.biodiversitylibrary.org. 